\title{
1. Polytropic Philippine: Intimating the World in Pieces
}

\author{
Patrick D. Flores
}

Reflecting on the theme 'world making', I was struck by two phrases that speak of the world as radically discriminating: 'a world like no other' and 'worlds apart' authenticate the singular and the different, which invoke the other, so that distance can be marked and the incomparable imagined. On the other hand, I would be reminded of certain modes of inquiry, such as 'world history' and 'comparative religion' that tend to encompass and include, to convene a multitude under the aegis of relationality or relativisation, which in turn survives the translations of context. This essay hints at a possible shift from the apparent antinomy between discrimination and inclusion, hostility and hospitality, the exceptional and the global, the indifferent and the comparable, mastery and sympathy.

In 1884, Filipinos who called themselves los indios bravos, or natives of the wild, gathered in a restaurant in Madrid to toast the triumph of their peers in the 1884 Madrid Exposition. Felix Resurreccion Hidalgo was conferred a silver medal for the work Las Virgenes Cristianas Expuestas al Populacho and Juan Luna received one of the three gold honours for the painting Spoliarium. That the Filipinos convened themselves in Europe was a fraught proposition: on the one hand, they entreated for reforms in the colony by way of inclusion in the Spanish Government and, on the other, laid the groundwork for a nation founded on exception, or exclusion from the empire, the site of their prolific exile, or their progressive other-worldliness. Spoliarium prefigures this aspiration as well to the degree that it mingles multiple moments of coloniality itself, or the various projects that have rendered the particularities of the world singular: the empires of Rome and Spain and the space for the exposition of art in the world. The scene in the painting is the cellar of the Roman colosseum where the cadavers of gladiators and slaves are stripped of their final effects and flung into the furnace. At the same event, where glasses were raised to exalt Luna and Hidalgo, Graciano Lopez Jaena read the picture as an allegory of the Hispanic condition in the Philippines:

For me, if there is anything grandiose, sublime in the Spoliarium, it is that through this canvas, through the figure depicted in it, through its coloring, floats the living image of the Filipino people grieving over their misfortunes ... the Philippines is nothing more than a Spoliarium in 
reality, with all its horrors. There rubbish lies everywhere; there human dignity is mocked; the rights of man are torn into shreds; equality is a shapeless mass; and liberty is embers, ashes, smoke. ${ }^{1}$

José Rizal, who would be executed for inspiring the revolution and become the country's pre-eminent patriot, sensed in Spoliarium a tale that was more than allegorical; for him, it was invincible evidence that the Philippine had come to belong to the world:

Luna and Hidalgo are Spanish as well as Philippine glories. They were born in the Philippines but they could have been born in Spain, because genius knows no country, genius sprouts everywhere, genius is like light, air, the patrimony of everybody, cosmopolitan like space, like life, like God. ${ }^{2}$

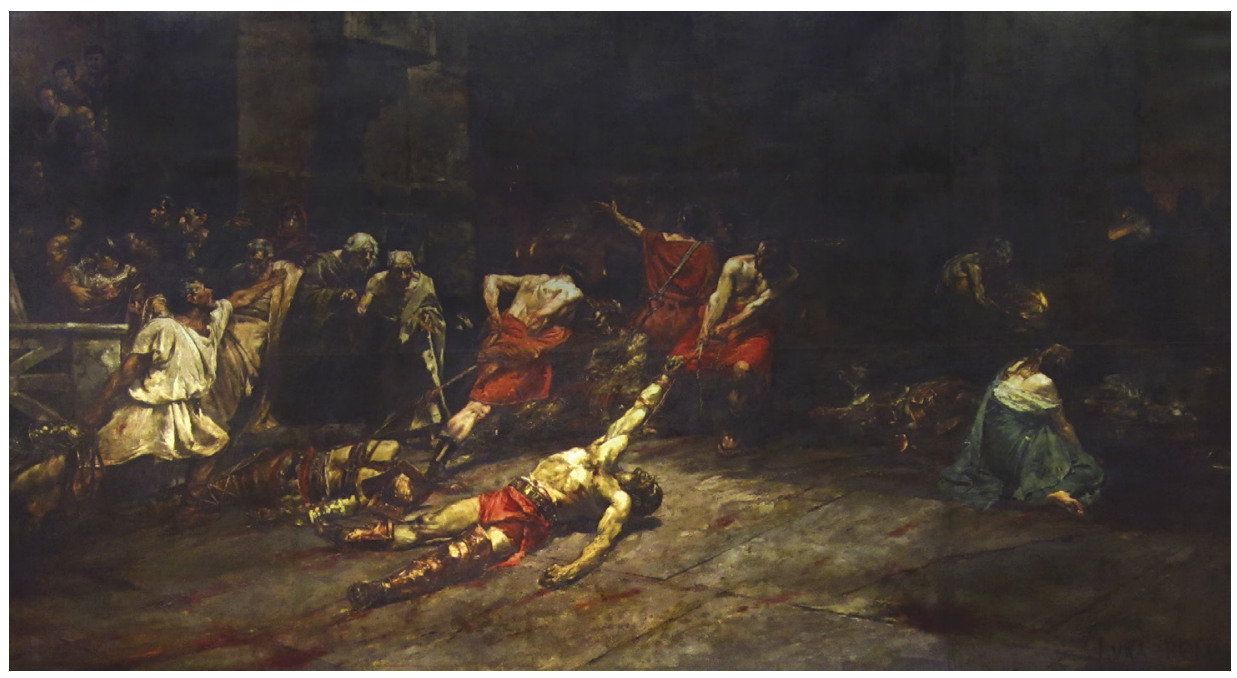

\section{Juan Luna, Spoliarium 1884; oil on canvas; 4.22 x 7.67 m.}

Photograph: Benigno Toda III; courtesy of the National Museum of the Philippines

Both Jaena, who felt that the locus of despoliation in Rome that was in Spain was also in the Philippines, and Rizal, who thought that the painter and the painting made the Philippine overcome the country that was colony and thus ratified its postcolonial ontogenesis, laid claim to a world at hand, in fact making it themselves because they grasped a continuum ethically and embodiedly,

\footnotetext{
1 Teodoro Agoncillo, ed., Graciano Lopez Jaena: Speeches, Articles and Letters (Manila: National Historical Commission, 1974), quoted in Zero In: Private Art, Public Lives (Manila: Eugenio Lopez Foundation, Inc., Ayala Museum, Ateneo Art Gallery, 2002), 78.

2 José Rizal, ‘Rizal's Speech Delivered at the Banquet in Madrid in Honor of the Filipino Painters Juan Luna and Felix Resurreccion Hidalgo (25 June 1884)', Political and Historical Writings / José Rizal (Manila: National Historical Commission, 1972), 78: 18.
} 
allegorically and performatively, immanently and imminently. It was simultaneously a repeating and a changing world, iterative like the unconscious and transformative like the politics that gripped Jaena and Rizal. But, as an astute critic would interject: 'If the unconscious is structured by repetition and the political by the desire for change ... the question, still, would remain one of knowing what the unconscious changes, and what politics repeats. ${ }^{3}$

In 1887, Rizal published his seminal novel Noli Me Tangere in Berlin. It is a microcosm of the Philippine colonial world, unfolding with the return of Juan Crisostomo Ibarra from Spain to find a ruined homeland, debased by avaricious friars and the petty elite, with his beloved woman forced to marry another man, becoming a nun, raped by a curate, and falling to her death. Early on in the novel, Ibarra walks into the narrative somewhat enchanted, or better still, bedevilled. As Rizal describes this scene of coming to Manila from Madrid, it would seem that the arrival and the arrivant were suspended in-between worlds, confounded by both 'loss and leaving':

The sight of the botanical garden drove away his gay reminiscences: the devil of comparisons placed him before the botanical gardens of Europe, in the countries where much effort and much gold are needed to make a leaf bloom or a bud open; and even more, to those of the colonies, rich and well-tended, and all open to the public. Ibarra removed his gaze, looked right, and there saw old Manila, still surrounded by its walls and moats, like an anemic young woman in a dress from her grandmother's best times. ${ }^{4}$

The historian Benedict Anderson translates 'el demonio de las comparaciones' as the 'spectre of comparisons', while the Tagalog writer Patricio Mariano nuances it as 'tukso ng pagkahawig-hawig', or roughly, the 'temptation of affinities' or 'phantasm of semblances'. In whatever way it is discerned, the phrase describes the condition or experience of mediating discrepant worlds coming together in an instance that is at once belated and present, and in a gap or interval that is at once memory and mimicry. In this situation, the local world exceeds itself and slips into the colonial world that is incommensurate, and the imperial world to which it pretends. The perplexed personage who is Ibarra, the doppelganger of the proto-national hero Rizal, stands in the midst of this demonio, that is, diabolical and therefore legion. It might, therefore, be productive to construe the other world as immanent critique because it presupposes at the outset an alterity that is always-already awaiting, in other words, imminent.

3 Barbara Johnson, 'Lesbian Spectacles: Reading Sula, Passing, Thelma and Louise, and The Accused', in Media Spectacles, ed. Marjorie Garber et al. (New York: Routledge, 1993).

4 José Rizal, Noli Me Tangere, trans. Ma. Soledad Lacson-Locsin (Manila: Bookmark, 1996), 67. 


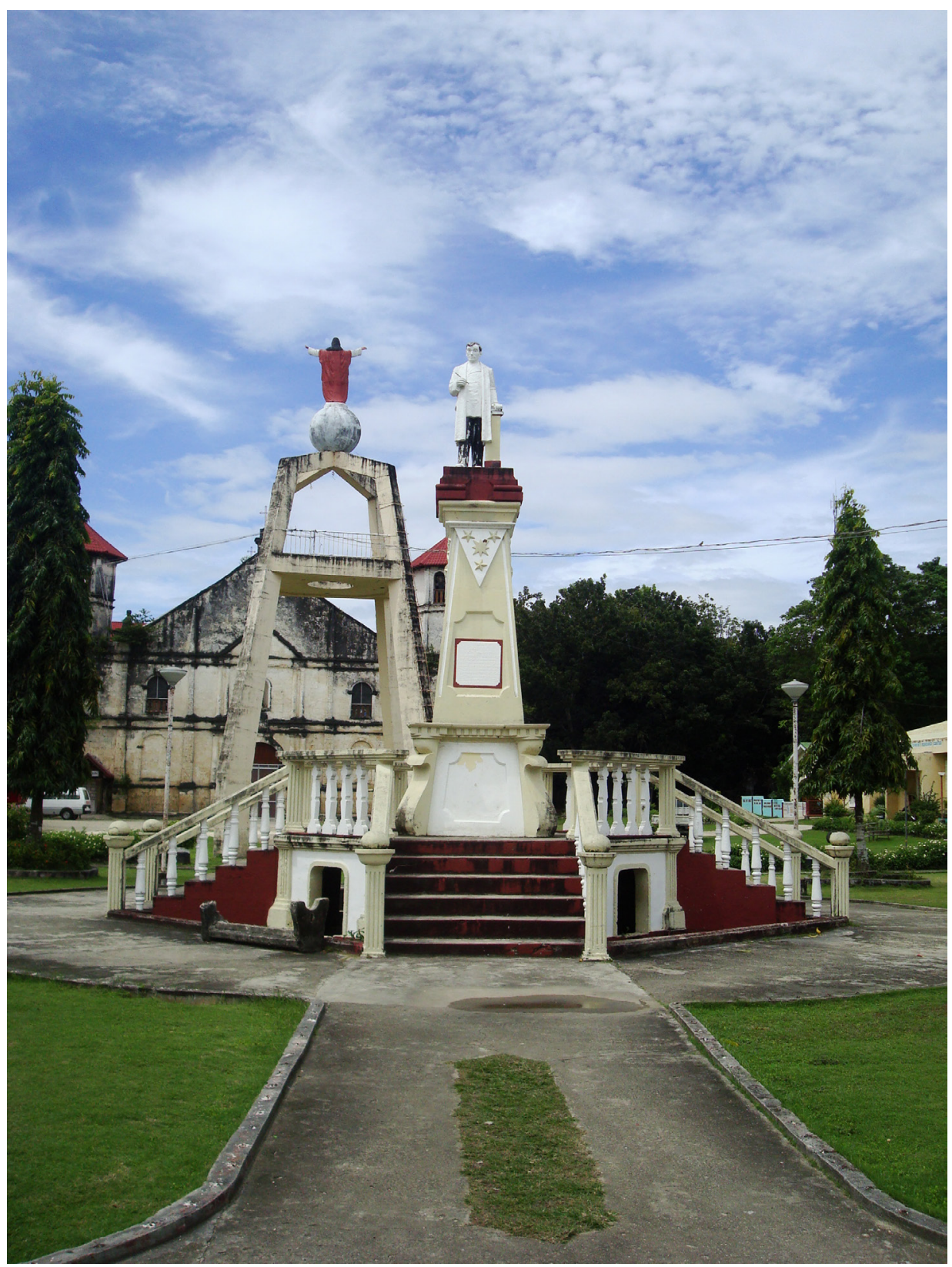

\section{Monument of José Rizal, Dimiao, Bohol.}

Photograph courtesy of the National Historical Commission of the Philippines 
In 1890, Rizal wrote copious annotations on a Spanish chronicler's description of the Philippines. Antonio de Morga, a lawyer who became the colony's lieutenant governor-general, wrote Sucesos de las Islas Filipinas, published in Mexico in 1609, to register what he saw and observed in the islands at the time of conquest: an ancientness that tried to historicise the Philippine, this figurine of an archipelago. The esteemed Lord Henry E.J.S. Stanley translated de Morga's chronicle into English and secured the imprint of the prestigious Hakluyt Society of London. Rizal engaged with the text, which he laboured to search at the British Museum, in the same spirit of knowing the Philippine as a 'culture' and therefore as a distinct ethnic universe. In this negation, he converses not only with de Morga's fiction, but also with the imagination that underwrites it. Rizal terms this act as 'annotations', formatted as footnotes to the main text, with marginalia creeping out like a metacritique. He envisioned this tract as a confrontation with the writing of the past on the islands and anticipates the story of a nation. He writes in the introduction, addressing the potential citizens of a polity: 'If the book ... succeeds to awaken your consciousness of our past, already effaced from your memory, and to rectify what has been falsified and slandered, then I have not worked in vain, and with this as a basis, however small it may be, we shall be able to study the future. ${ }^{5}$ In one of these insertions, he spins a polemic around a contentious entry:
Death was always the first sign of European civilization upon being introduced into the Pacific and God wills that it may not be its last, because, judging by the statistics, the islands of the Pacific being civilized are depopulating terribly. The first exploit of Magellan upon arriving at the Marianas, was to burn more than forty houses, many vessels, and seven inhabitants for having robbed a boat; those hapless savages saw nothing bad in robbing, which they did so naturally, just as among the civilized fishing, hunting, and to subjugate weak or ill-armed people. ${ }^{6}$

In this reconnaissance project, or the procedure of retrieval, Rizal enacts a redemptive process, redressing the error of colonial recordation, and inevitably asserting a self-consciousness about history and its artifice as a mode of writing the world. To a certain extent, Rizal here continues to grapple with the temptation of affinities, disconfirming the disfiguration of knowledge and refiguring the Philippine grotesque or picturesque that was to be reified as the Philippine primeval. In other words, he dwells on the particularity of ethnicity and the islands that contain it, or on the ethnographic that describes its distinction and, in doing so, affirms the universality of his being equivalently human as a native, a writer of history, and an interlocutor of empire. That he would extend this

5 José Rizal, Historical Events of the Philippine Islands by Dr. Antonio de Morga (Manila: José Rizal National Centennial Commission, 1962), vii.

6 Ibid., 64-65. 
particularity to a differentiated universality through the typification of culture of the Philippine and later of the Malay is germane because it insinuates a dissent to dominant worlding. The latter may be characterised as Western, occidental or European. When Rizal states that 'despite the contact with Western nations, whose ideals are distinct from theirs, we see the Malayan Filipinos sacrifice everything, liberty, comfort, welfare, name, on the altar of an aspiration ${ }^{7}$ he, in a way, instrumentalises the Malay trope to galvanise a 'counter-hegemonic' project of a future 'national identity.' This is not to argue, however, that the Philippine is beyond the pale of the Malay ecumene; scholarship affirms otherwise, with one Filipino historian contending that 'Philippine forms' started to surface from 200 BCE to 1565, within a dunia Melayu or the Malay world. ${ }^{8}$ Also, Rizal in his appropriation of the Malay as vector of his identity, would be esteemed as the 'greatest man the Malayan race has produced' in his time and likewise in the present in which the Malaysian dissident Anwar Ibrahim nominates Rizal as the 'first Malayan'. A noted Malay scholar considers Rizal as the first 'systematic social thinker in Southeast Asia' ${ }^{\prime 9}$ who offered a theory of the colonial condition and a theory of emancipation.

This sequence of incidents and texts from Rizal constellates a possible worlding in which the Philippine yields manifestations of its place in the world together with the discourse of that emplacement. It posits a relationality not only by imbricating itself within the system, but by intimating that system in pieces, like islands in an archipelago - an archipelago effect. First, it casts the colonial subject as a genius that transcends country and assumes the inalienable property of nature. Second, it stages an aporetic encounter: the self recognises its origin through a colonial double vision, which is then critiqued as the basis of the origin's desolation. Third, it revises the writing of its history by presenting it and then putting it under erasure, redeeming it from a European episteme. Here, the world ceases to be outside the Philippine. As in a devotional contract, the Philippine in its toil to imitate - to identify with and resemble - and suffer the world, or that which encompasses it, becomes an intimate that secures the right to make demands of equivalence and kinship, the entitlement to importune. ${ }^{10}$ It is this intimacy of the Philippine with the world that may have enabled it to be a country of migrants and mariners, and wherever they settle offer affective labour as givers of care and keepers of house, performers, and raisers of children and therefore suffuse the interior of well-being, emotion, and home.

7 Ibid.

8 R.A. Curaming, 'Filipinos as Malay: Historicising an Identity', in Melayu: Politics, Poetics and Paradoxes of Race, eds Maznah Mohamad \& Syed Muhamad Khairudin Aljunied (Singapore: Singapore University Press, 2011), 241-74.

9 See the work of Syed Farid Alatas.

10 Fenella Cannell, Power and Intimacy in the Christian Philippines (Cambridge: Cambridge University Press, 1999). 
It is uncanny that the Filipino author Jessica Hagedorn's 2003 novel Dream Jungle opens with a citation from Antonio Pigafetta, the chronicler of Ferdinand Magellan, the Portuguese discoverer who was the first person to circumnavigate the globe and was killed in the Philippine islands by a local chieftain in 1521. In the quoted account, Pigafetta (in Primo Viaggio Intorno Al Mundo) regards the conquered territory with derision:

Those people are poor, but ingenious and very thievish, on account of which we called those three islands the islands of Ladroni (i.e. of thieves). Their amusement ... is to plough the seas with those small boats of theirs ... those boats resemble the dolphins which leap in the water from wave to wave. Those Ladroni ... thought ... that there were no other people in the world but themselves. ${ }^{11}$

In the same spirit, Hagedorn retraces the conquistador's gaze over the domain with this opening passage, as if to mimic the primal scene of colonialism:

Zamora's gaze was steadfast and shameless. O they were beautiful, powerful, strange! Their fierce, wary eyes scrutinized him in return, taking in the brown, unruly curls on his head, the scraggly beard of his pale, unshaven face, the muscular arms and small, compact body that was, surprisingly, no taller than theirs. He had walked into a dream ... The landscape of that dream - vast, ominous, shimmering blues and greens - was simply part of the loot. ${ }^{12}$

Here, the mingling of the ethnographic and the sublime, to form what may be framed as the 'ethnographic sublime', runs through from Rizal in the explication of wonder or astonishment over the other that is styled in an array of ways: as primitive, as civilised, as abject, as transcendent. To complicate this coincidence further is Hagedorn's heroine Rizalina (an appellation that is both the feminisation and diminution of Rizal), the daughter of a servant of Zamora Lopez de Legazpi, a rich, notorious philanderer who discovers a purportedly Stone Age tribe in the Philippines. This is obviously an allusion to Manuel Elizalde, a tycoon with interests in mining in Manila during the regime of Ferdinand Marcos, who was supposed to have discovered the Tasaday in rainforests on the southern island of Mindanao. This sensation turned out to be partly a contrivance, an attempt by a Third World nation-state to heighten its civilisational master narrative in the age of the international, and to prop up evidence of the 'original Filipino', who existed before the era of colonialism and before the reckoning of Rizal, who one biographer describes as the First Filipino.

11 Jessica Hagedorn, Dream Jungle (New York: Penguin Books, 2004), 3-4.

12 Ibid., 5. 
Elizalde, who was appointed by Marcos as presidential assistant on national minorities, idealised the Tasaday as the indigene or autochthone without peer, having no acquaintance with the outside world. According to John Nance: 'They were offered corn, camote (a kind of potato), taro, and cassava. They apparently had no names for these things - staples among nearby mountain people - and indicated they had never seen them before. ${ }^{\prime 3}$

The Hagedorn character Rizalina is molested by Legazpi (incidentally, the name of the Spanish official who founded the city of Manila) and, after leaving the Zamora household she becomes a sex worker in the city, where she meets an American, Vincent Moody, who is in the country to shoot the Vietnam film Napalm Sunset. The evocation of the primitive and of Hollywood is salient because it inevitably summons Francis Ford Coppola's 1979 US\$30 million magnum opus Apocalypse Now, the high-flying production that the auteur filmmaker calls not a film on Vietnam but is, in fact, Vietnam-despite it having been shot in the Philippines. The conflation of Vietnam and cinema as excursions of excess, and as phantasmagoria and psychopathology may have been a conflation of Vietnam/cinema and the Philippine as well. After all, Coppola plays out his Vietnam fantasy and the hellish means of making it possible in the Philippines, which served as the material condition of filmmaking and the surrogate of the historical subject. The film, which pursues the premise of Joseph Conrad's Heart of Darkness (first published as a three-part serial in 1899), stages the ordeal of four men, Willard and his confreres, who are tasked to slay a renegade American soldier in Vietnam named Kurtz, played enigmatically by a hefty Marlon Brando, who has conducted his own operations in Cambodia, portrayed here as a path paved with human skulls. They find him as a lord in dominion amid the ethnic community of the Montagnards, who are fleshed out cinematically as Ifugao, a northern group in the Philippines that performs their ritual of bounty through the actual slaughter of a water buffalo. In this situation, the Philippine becomes exceptionally tropical, at once nature and ideology, inalienable and phantasmatic, bare life and sheer trace, a 'turning earth'.

Such a scenography is astutely calibrated by the Italian cinematographer Vittorio Storaro, who was enlisted by Coppola to lend grace to the film's exterior, his camera gliding or even skittering on the tension of the surface, bathing it with the ether of napalm, the quiet blaze of fire, or the luminosity of the filtered light of a surely stunning sun. This dreamscape is co-extensive with Hagedorn's recollection of her homeland, the Philippines: she remembers it as 'a sinister yet inviting apparition - on a tiny, uninhabited island in the middle of a shimmering sea. I kept trying to swim to the island but never got there, no

13 John Nance, The Gentle Tasaday: A Stone Age People in the Philippine Rain Forest (New York: Harcourt Brace Jovanovich, 1975), 13. 
matter how hard or fast I swam. The house and the island kept vanishing into the distant horizon, reappearing again and again like some cruel optical illusion. I often woke from those dreams in tears, furious with myself for being weak. ${ }^{14}$ This interspersing between recollection and its ruse aestheticises the politics of belonging to the world or repossessing it altogether. Here, the technology of this aestheticisation partly derives from the mediation of the Philippine, the site of the deterritorialisation and the bricolage. When Hagedorn interviews the primitivist demigod and benefactor Elizalde, from whom her character in the novel is hewn and is analogue of the mythologist Coppola, her consciousness is saddened, in the register perhaps of Rizal's demonio de las comparaciones, by an eccentric reverie:

In the middle of one of our long, heavy silences, a shape suddenly materialized on the parched green lawn. He was a lithe young boy with skin the color of mahogany, clad in a loincloth. A red hibiscus was tucked in his thick, black lion's mane of hair. The boy loped past us - almost dancing - on that sun-baked terrace, ignoring our presence. He warbled in a high-pitched voice as if he were singing or calling out to someone. Then with one last amazing leap, the boy vanished into the big white mansion. Elizalde didn't react. I wonder now if he had staged the performance for my benefit, if he were somehow making fun of me. Did I hallucinate the wild child with the flower in his hair, the eerie song, the entire episode? Was he a Tasaday in captivity, flown all the way to Manila to be part of Elizalde's private and intensely personal world's fair?'15

In the filming of Apocalypse Now, the helicopters that Coppola borrowed from the Philippine Government had to be withdrawn every so often because they were required for the existing conflict with Maoist insurgents in the countryside. The Philippine, therefore, was not only a materiel for film; it, in fact, comprised the history of the European and American theatre of operations in South-East Asia, a continuum that is denied by the reduction of the war to some kind of psychedelia, a 'rock and roll' war, according to the god-director, who himself was taken in by the irrationality of it all. In the end, with the war being conceived as out of this world, the lifeworld of the Philippine recedes into a universal whimsy of ritual and antiquity, a timelessness, the incomprehensible but irresistible exotic. ${ }^{16}$

14 Jessica Hagedorn, 'Ghost Town', Time Magazine, 18 August 2003, 36.

15 Ibid., 37.

16 Victor Segalen, Essay on Exoticism: An Aesthetics of Diversity (Durham: Duke University Press, 2002). 
The contemporary Filipino visual artist Stephanie Syjuco recognises the Philippine in Apocalypse Now, and other Vietnam War-themed films, such as Platoon and Hamburger Hill, and seeks to recover the locale by deleting that which has encroached on it; that is, that which the film has fabricated, the very scenography of Vietnam. In the three-channel work Body Double, she reverses the ethnographic sublime and restores, as it were, the natural via a montage of the elements: silent, uninhabited, uncorrupted by so-called culture, the ecology of the Philippine, the diversity of which is one of the broadest in the world, that is recuperated as atmosphere. As Syjuco confides: 'This video project ignores the original filmic narrative to focus on my own attempts at discovering my place of birth - a kind of reworked "home movie". The resulting videos look like ambient, minimalist imagery of landscapes and closeups of flora and fauna. ${ }^{17}$ Again, the Philippine becomes figurine and intimate.
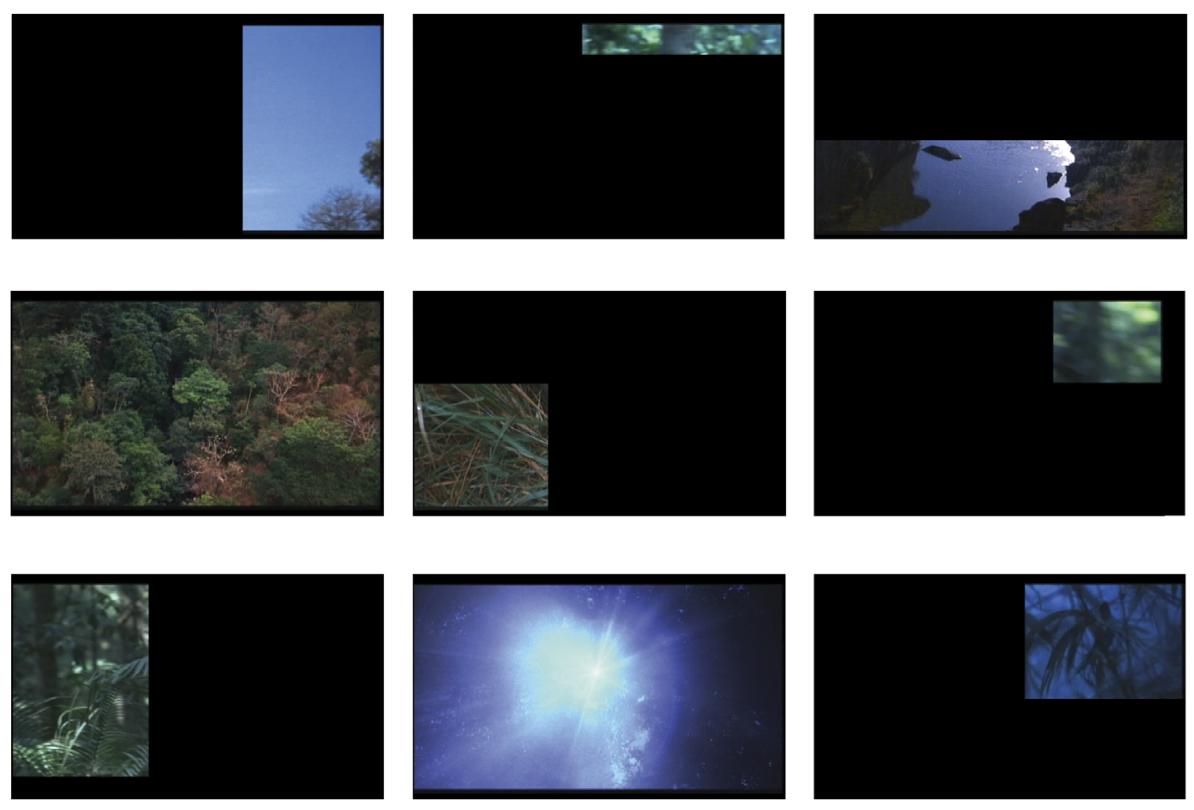

\section{Stephanie Syjuco, Body Double (Platoon / Apocalypse Now / Hamburger Hill) 2007 (video still); 3-channel video installation; $120 \mathrm{~min} / 150 \mathrm{~min} /$ $100 \mathrm{~min}$.}

\section{Courtesy of the artist and Osage Gallery}

The terrain, while lush and plenty, happens to have a precarious life. The tropical is blessed by profuse parturition, on the one hand, and it is site of calamity and ruination, on the other. The Centre for Research on the Epidemiology of

17 Stephanie Syjuco, 'Body Double (Platoon) 2005', http://www.stephaniesyjuco.com/p_bodydouble.html. 
Disasters reports that, since 1900, the 'Philippines has experienced the most events defined as requiring international assistance. ${ }^{18}$ Between 1900 and 1991, there was an average of eight disasters a year, making the country the hardest hit by natural disasters in 90 years. This is another condition of the 'apocalypse,' the destruction of the natural world, the decimation of population, the devastation of heritage. Such feeling of transience is key in grasping the Philippine mood for the otherworldly: migratory or millenarian, 'errant in form but firmly rooted in its essence' to borrow a phrase from the baroque philosopher Jose Lezama Lima. ${ }^{19}$ The confluence between species and milieu, biologies and natural histories, in what the anthropologist Aihwa Ong calls 'biopolitical assemblages', bears on how global economies continue to colonise conditions of vital survival and how this very survival valiantly tries to frustrate it. As she elaborates: 'Sheer life in the tropics is becoming an ethical exception to the global cartography mapped and sustained by the biocapital regime. ${ }^{20}$

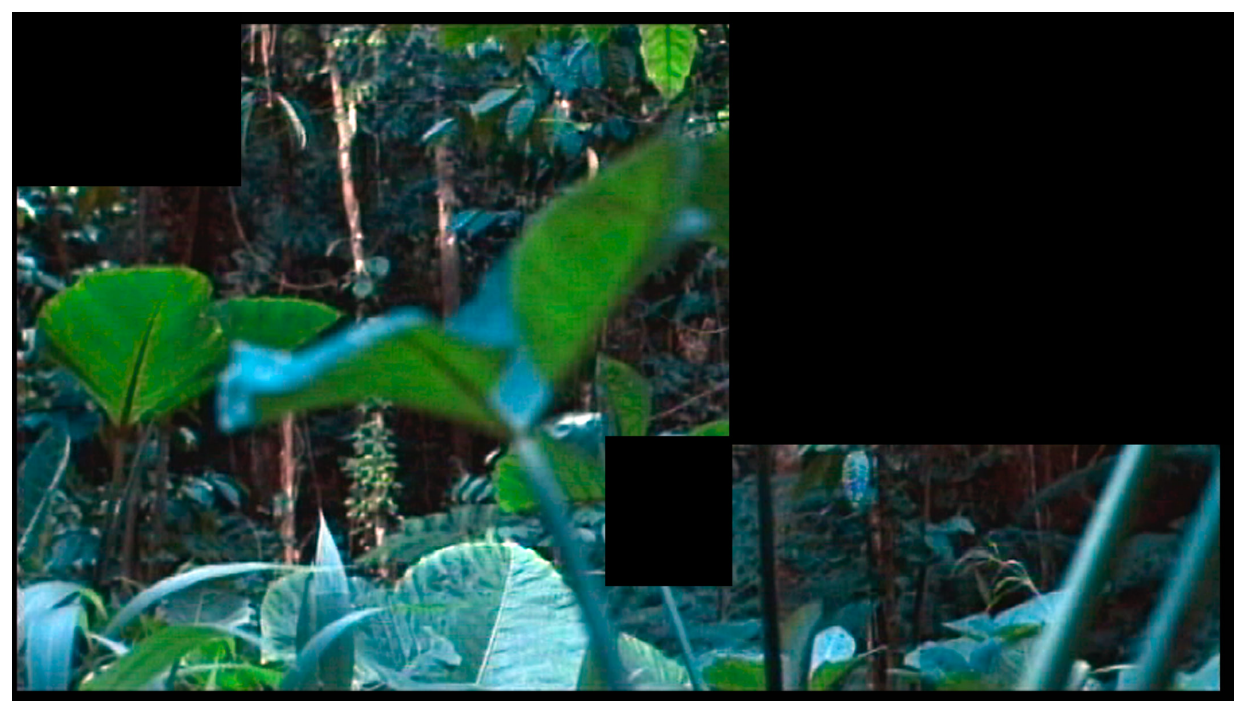

\section{Stephanie Syjuco, Body Double (Platoon / Apocalypse Now / Hamburger Hill) 2007 (video still); 3-channel video installation; $120 \mathrm{~min} / 150 \mathrm{~min} /$ $100 \mathrm{~min}$.}

Courtesy of the artist and Osage Gallery

\footnotetext{
18 Greg Bankoff, 'Storms of History: Water, Hazard and Society in the Philippines 1565-1930', in A World of Water: Rain, Rivers and Seas in Southeast Asian Histories, ed. Peter Boomgaard (Singapore: NUS Press, 2007), 153.

19 Jose Lezama Lima, 'Baroque Curiosity', in Baroque New Worlds: Representation, Transculturation, Counterconquest, eds Lois Parkinson Zamora \& Monika Kaup (Durham: Duke University Press, 2010), 213.

20 Aihwa Ong, 'Scales of Exception: Experiments with Knowledge and Sheer Life in Tropical Southeast Asia', Singapore Journal of Tropical Geography 29 (2008): 7.
} 
The inclusion of the Philippine and the exclusion of the Vietnamese in Syjuco's videoscape need not be viewed in the binary terms of inside/outside, with the Philippine merely reduced as location to be animated by the cinema, which is later excised from the mise en scène. It might be more productive to contemplate that, in the vein of earlier reflections, the Philippine is within, internal or internalised, impersonating though neither totally assimilated nor hybridised. This is cogently articulated in the way in which Filipino performers would be conscripted by Broadway to play the role of the Vietnamese in the musical Miss Saigon, based on Puccini's Madame Butterfly, with music and lyrics by French musicians Claude-Michel Schonberg and Alain Boublil. The tale is inspired by a picture of a mother giving up her daughter in the frenzy of the fall of Saigon in 1975. The lead character is Kim, who works in a bar where she meets Chris, an American soldier stationed in South-East Asia. He leaves her and their child when he returns to America and comes back for the boy with his American wife; Kim kills herself for her firstborn. A pivotal image in this drama of love and desertion is the helicopter, the vehicle of violence and recapture. In Apocalypse Now, a squadron of helicopters swoops down on a school and rice fields to the operatic strains of Wagner's Ride of the Valkyries and, in one sequence, it hurriedly airlifts scantily clad American girls who had been brought to Vietnam to titillate the troops. At a certain point in their burlesque, the soldiers turn into a mob and nearly gang rape them. The helicopter, as a trope of escape, is central in both the film and the play, rescuing the child of the self-immolating mother and the flesh of the women defiled by men.

With Apocalypse Now and Miss Saigon, the history of South-East Asia in the Cold War emerges through the performance of the Philippine. It is the natural and ethnographic sublime of the Philippine, along with the affective labour of the Filipino, that this imaginary manifests and creates emotional capital. There is a scene in Apocalypse Now, which has been cut out of the original release but which was later added in the more integral version, Apocalypse Now Redux, that condenses the South-East Asian conjuncture. In the quest for Kurtz, Willard's group snakes its way through a river and chances on a French plantation. Willard sits with the French expatriates through a genteel dinner, during which he asks why the colonists stay, to which one of them retorts: 'Because it is ours.' This intersection between the French and the American in Indochina, as made possible through the site that is the Philippines, is emblematic to the degree that it unravels the symptoms of a possible racial melancholy, stirred up by the lost objects of both empires and their longing for them as possessions. It is at this node of the rhizome that the grisly Philippine-American war projects itself. If the Cold War is to be reckoned in South-East Asia, the American imperialism in the Philippines, beginning in 1899, must be sharply indexed, carved into high 
relief by the Philippine-American war that left one out of seven Filipinos dead, making it the 'first Vietnam' and also a 'proto-Iraq'. As President George W. Bush pointed out in a speech before the Philippine Congress in 2003:

Democracy always has skeptics. Some say the culture of the Middle East will not sustain the institutions of democracy. The same doubts were once expressed about the culture of Asia. These doubts were proven wrong nearly six decades ago, when the Republic of the Philippines became the first democratic nation in Asia. Since then, liberty has reached nearly every shore of the Western Pacific. ${ }^{21}$

The implication of the Vietnam War is, moreover, consequential largely because it motivated the disposition of critique in Europe and the rise of its avant-garde. The 1968 student upheaval in Paris expended critical energy that infused the avant-garde, to which contemporary art turns for impetus, up to the present. It is, therefore, not to overstate that South-East Asia as a setting is exemplary because it has coordinated both the imperialism of the West and the resistance of the world against it, wherever it found itself.

When Miss Saigon premiered in London in 1989, it launched its star, the Filipino Lea Salonga, in the role of Kim. It opened on Broadway in New York two years later. Succeeding franchises of the play in around 25 countries and 246 cities have also had other Filipino talents in the lead. As early as 1925, Filipino soprano Jovita Fuentes played Cio-Cio San in Puccini's Madame Butterfly at the Teatro Municipale di Piacenza. There is a high degree of relay here from the local to the global, the self to the other in the performative utterance of, let us say, the Filipina actress essaying a Vietnamese heroine in English through a type of singing that is based on Western popular music and a musical theatre arising from vaudeville. Salonga, who auditioned for the part in Manila in an international search for the cast, was already a theatre and media personality, having appeared in The King and I when she was seven. While the narrative in the Philippines at that time was triumphalist, viewing the appearance of Filipino artists on the world stage as a conquest of the West, not far from the homage to Juan Luna's own conquest in Madrid a century earlier, what should not be missed is the underlying sadness of having to re-dramatise the tale of conquest so that the self could outlive the despair of its tropics, something that remarkably perturbed Rizal's persona in his novel. The global travel writer Pico Iyer was moved by the breathtaking talent of the Filipino to imitate the West by simulating 'every shade of heartbreak' and thus turning into 'musical mannequins' gripped in the vice of an 'eerie kind of ventriloquism. ${ }^{22}$ The

21 George W. Bush, President of the United States 2001-2009, 'Remarks to a Joint Session of the Philippines Congress in Quezon City, Philippines', 18 October 2003, http://www.presidency.ucsb.edu/ws/?pid=63501. 22 Pico Iyer, 'The Philippines: Born in the U.S.A', Video Night in Kathmandu: And Other Reports from the Not-So-Far East (New York: Vintage, 1989). 
anthropologist Fenella Cannell is attentive to this kind of affect in her take on why a contestant in an amateur singing contest on a peninsula south of Manila could croon the standard Autumn Leaves with so much wistfulness that it gave the foreign observer the impression that the reality of autumn is deeply felt in the culture and so could be expressed so inalienably in music through a voice so unbelievably authentic. The risk of performing this alien sound requires the influence of spirit, the need to be drunk to be able to cross the gap between the everyday and the elsewhere. According to Cannell:

It seems possible that one element in the 'sentimental' and nostalgic atmosphere of the singing is built precisely out of the origins of that risk; the loss that the author signified by 'Autumn Leaves' makes no immediate sense in the tropics, but the idea of loss itself does; in singing a song part of whose meaning escapes one, one evokes, among other losses, the sadness at not having completely understood, at being excluded in relation to a cultural register which, if one masters it, can open the doors of possibility and change one's life. ${ }^{23}$

Inscribed in this series of coincidences, therefore, are the history of empires and the development of nation-states in South-East Asia during the Cold War, partly through the export of human labour, the allure of economic advancement attending the desire for democracy as contrasted with the regimentation of socialism that surrounded the region. It is in this locus that the anxiety of a certain loss of ethical ascendancy via the revolution, and its negation via imperialism, that Europe and America, or Euro-America through France and the United States, distills in the performance by the Philippine in the culture industry of Broadway. The French makers of Miss Saigon previously staged Victor Hugo's Les Miserables, reinforcing the thought that, as with Coppola, Schonberg and Boublil are disillusioned by the revolutionary/imperialist double vision and appeased by the perfect(ed) Philippine performance of bereavement and benevolence. It must be noted that in 1980, a refugee processing zone opened in the Philippines under the auspices of the United Nations and the US State Department; it prepared refugees from Indochina for their settlement in Europe and America. But the Philippines also hosted the largest US military bases outside of the United States, which were utilised as platforms for naval operations during the Korean and Vietnam wars and as a strategic geopolitical foil of deterrence in the area due to their proximity to the Soviet installations in Cam Ranh Bay in Vietnam.

Mediating this convergence is the polytropic Philippine. The critic Peter Hulme remarks that the term polytropic pertains primarily to mobility, deriving from the epithet for Odysseus as a 'man of many ways' and may also mean 'much

23 Cannell, Power and Intimacy, 209. 
travelled', 'given to troping', and 'cunningly intelligent' ${ }^{24}$ The latter is linked to metis, the idiom of quick change, originally a word from navigation signifying the 'skill needed to find one's way across a piece of water and out of sight of land ... a particular kind of resourcefulness ... the ability to become multiple, Protean, in order to deal with situations which are shifting and disconcerting, situations unamenable to precise measurement or exact calculation, the ability to find a way out when the way ahead is blocked. ${ }^{25}$ While Hulme uses polytropic to describe individualist ethos and colonialist duplicity, exemplified by men who 'covet the land whose inhabitants they confront, and therefore lie about the reasons for and circumstances of their coming, ${ }^{26}$ it is refunctioned here to return the look, so to speak, with the Philippine remaking itself from a colonial object to a subjectivity that comprehends back; indeed, a dissemination, like the worldly Rizal or the archipelagic effect, and the intimacies that permeate spaces which refuse the humanity it persistently intimates. In Hulme's mind, the polytropic man is an intruder, beholding his singular acts of settling. In this instance, the polytropic Philippine is temporary, alien or exile, guest worker or second family, surrogate mother or housekeeper, first teacher or mail order bride, plural in its sympathies, assuming the grief of others and suffering its own, moving - mobile and heart wrenching, modern and melodramatic - and compassionate in many ways, that is, suffering together with passion.

The polytropic may finally be gleaned as a genius transcending culture that is repatriated as a native, a self-conscious subject that needs to be compared with others. This is indicated in an anecdote shared by Rizal with his good friend, the Austrian ethnologist Ferdinand Blumentritt, with whom he had extensive epistolary exchange. In one of these letters, Rizal recounts his meeting with the eminent pathologist and liberal political figure Rudolf Virchow at an event in 1887 of the Berlin Society for Anthropology, Ethnology, and Prehistory, to which Rizal would be later admitted. Virchow was said to have told Rizal teasingly that he wanted to study him ethnographically. ${ }^{27}$ Again foregrounded in this ludic encounter is the ethnographic as a measure of culture and its inherent comparisons and, surely, the comparability of Rizal and his sense of belonging to the world. In Virchow's obituary for Rizal, he considers him 'the only man with sufficient knowledge and resolution to open a way for modern thought into that far-off island world.' This leads us to ask: Was Rizal an exception or did he solicit the recognition of Europe to affirm the civilising mission and become its diffusion? Was he a convenient specimen assimilated by the liberal flank of German intellectuals in the time of the nationalist

\footnotetext{
24 Peter Hulme, 'Polytropic Man: Tropes of Sexuality and Mobility in Early Colonial Discourse', in Europe and Its Others: Proceedings of the Essex Conference on the Sociology of Literature, vol. 2, eds Francis Barker, Peter Hulme, Margaret Iversen \& Diana Loxley (Colchester: University of Essex, 1984), 20.

25 Ibid., 21

26 Ibid.

27 Rizal's Correspondence with Fellow Reformists (Manila: National Heroes Commission, 1963).
} 
Bismarck who postured as espousing progressive politics? Or was Rizal so truly universal in his temperament that the foreign was hospitable to his difference or transculturality? Did someone like Rizal, a native from a colonised archipelago, finally become a worldly agent who performed the rituals of residing in the world and pursued a script of extensity, or palabas, ${ }^{28}$ the Filipino term for both a dissembling or disguise and a movement towards an outside? After all, Rizal was self-conscious about how his death would transpire; he, in fact, had dreamt it and asked executioners not to shoot him in the head. When the bullets were fired, he turned to face them with dignity. This ethical and performative stance ensured that the palabas, the spectacle of heroism, would assume its proper potency and its effect would further inflect the Philippine consciousness, from spiritual movements who hail him as the Tagalog Christ and the emergent film industry, the early manifestations of which in South-East Asia magnified the drama of his martyrdom as both historic and cinematic.

This rumination on the polytropic Philippine tries to carve out a different circuit for the Philippines, so that it can be seen as part of a South-East Asian relay of relations. Oftentimes, the Philippines falls off the map of the region because it does not manifest the legacies or monuments of the great traditions of India and China. But a study of the other routes of encounters should rectify this notion. The widening of the latitude of the Philippine through its polytropic potential is one such effort. It recasts the condition of an at once appropriated and appropriating subjectivity and dwells within what Foucault calls the 'sudden vicinity of things', or what the theorist of visual time, Keith Moxey, calls 'productive adjacencies'.

The Philippines in 2011 commemorated the sesquicentennial of Rizal's birth, fully reminded of his ubiquity in everyday life as a national hero, even if there has been no edict proclaiming him as one. If the monument were testimony to this reverence, it would also be an index of the liberties the people have taken in portraying him in pieces, as his likeness and its mutations mark nearly every town in the country and the communities across the globe of Philippine migration in which he is a compelling cipher of identity amid the most intense of discriminations. Rizal might just be the most monumentalised person in the world, something that further complicates the term polytropic, and one can argue that Rizal is within in the same manner that the Philippine is the world within.

28 See Patrick D. Flores, 'Palabas', Ctrl+P Journal of Contemporary Art, no. 11 (2008): 8-9, http://www. ctrlp-artjournal.org/pdfs/CtrlP_Issue11.pdf. 


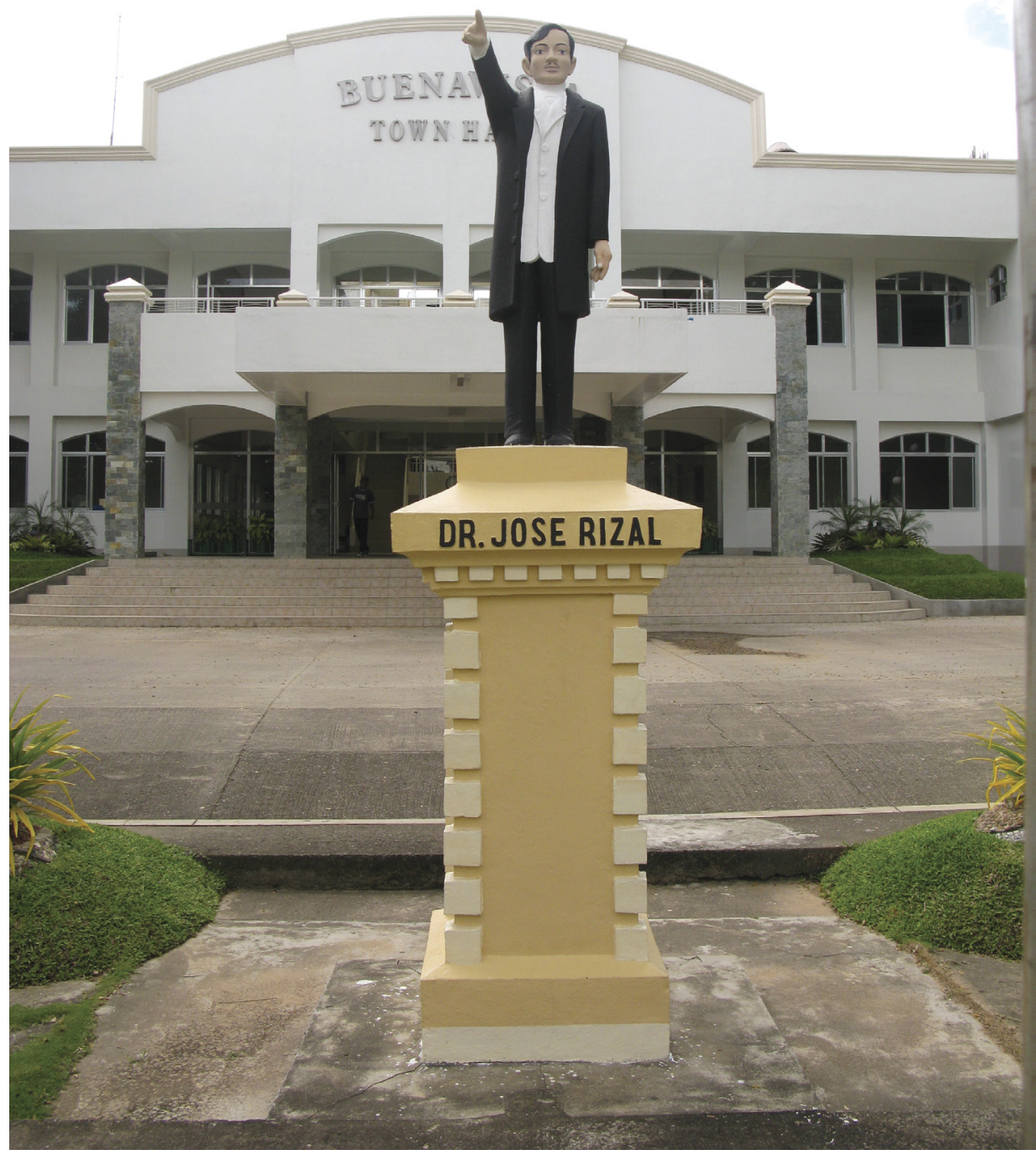

Monument of José Rizal, Buenavista, Guimaras.

Photograph courtesy of the National Historical Commission of the Philippines 
This dispersal of the heroic and the intimations of the Philippine across spaces may be seen in a recent project involving Filipino overseas workers in Hong Kong, who have been called the modern-day Filipino heroes for their indispensable remittance; like Rizal, their histories are exilic, too. In 2009, the Chinese artists Sun Yuan and Peng Yu asked a hundred Filipino domestic workers, mostly women, in Hong Kong to plant a bogus grenade inside the splendid houses of their employers and photograph the tableau, the still life, the interior. This clandestine task and its tense imagery risk the imagined security and secret of the abode as well as the persons who keep it and who now guarantee the exposure of property. They are disclosed only partially in the form of bodies turned against the viewer, standing like memorials of their infiltrating deed. Through the aesthetic of the camera in the digital age, they design this unease in cohabitation, an embeddedness, the tactic of a guerilla or an interloper or a grenadier. In the multiplicity of bodies and houses and bombs, the trauma of migration, of biopolitical traffic and private life, repeats and is distributed. But this repetition and distribution, this accumulation of labour and capital, likewise ensures the settling of the human globally and, at last, a community beyond country and of aliens with the rights of others. ${ }^{29}$ It is said that a third of the Philippine population lives beyond its islands, around 4,000 leaving every day, eight million of them toiling abroad to keep the economy on an even keel by sending home around \$US20 billion a year in remittances, and countless of them coming home as corpses.
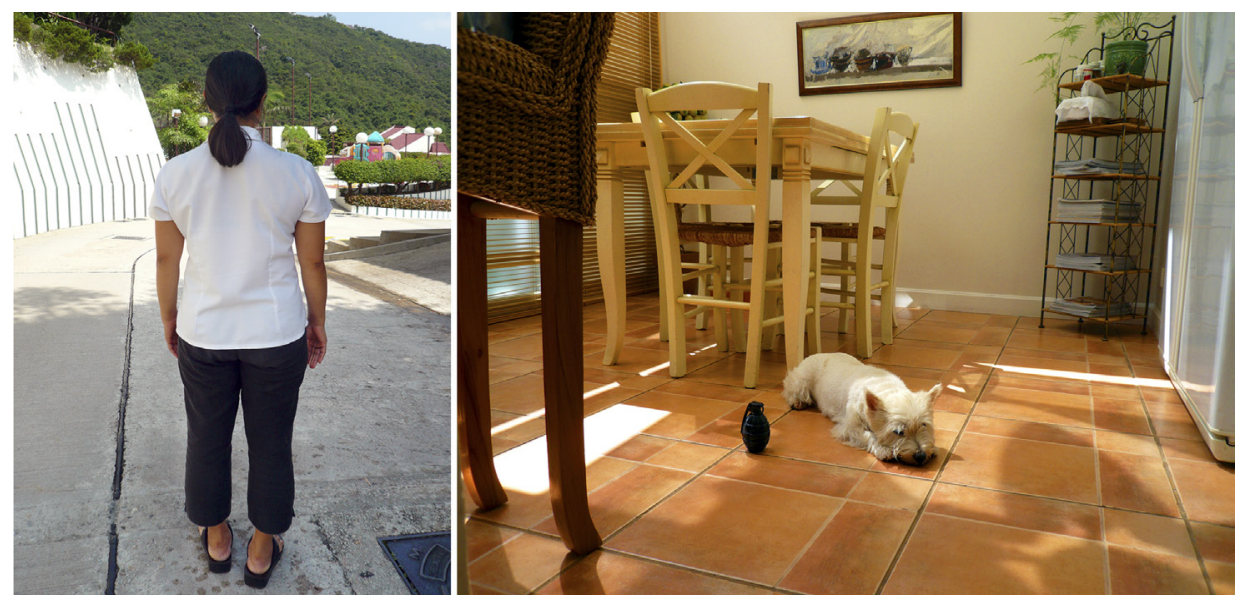

Sun Yuan \& Peng Yu, Hong Kong Intervention 2009; 200 C-print photographs; $75 \times 100 \mathrm{~cm}, 75$ x $56 \mathrm{~cm}$ (each pair); edition 1 of 3 .

Courtesy of the artists and Osage Gallery

29 See Agnes Lin, ed., Hong Kong Intervention (exh. cat.; Hong Kong: Osage Gallery, 2011). 
The body of Filipinos is a ticking migrant force in the accommodations of their masters. The volatile device they smuggle in, at once plaything and terrorist prop, may well be the bomb of deterritorialisation, a potential threat that sits quietly on the fireplace or the carpet or close to a cat, finally replacing identity and homeliness with intimation, or what a scholar calls the 'diasporic of melancholy' ${ }^{30}$ and what a curator depicts as the 'beauty of distance. ${ }^{31}$ It may well also be an incendiary imminence, the postcolonial polytrope of immanent critique, that proverbial blast from the past, nothing less than the horror and catastrophe as well as the thrill and fearlessness of belonging in a world that refuses the hospitality, migrancy, and rights of others whenever the latter threaten the privileges of settlement. In 2013, the highest court in Hong Kong ruled that a foreign domestic worker, a restrictive category of migrant, can never be granted permanent residency.

\footnotetext{
30 See Sarah Brophy, 'Angels in Antigua: Diasporic of Melancholy in Jamaica Kincaid's My Brother', PMLA 117 , no. 2 (2002): 265-77.

31 This is from the title of the 17th Biennale of Sydney: The Beauty of Distance: Songs of Survival in a Precarious Age, curated by David Elliott, 2010.
} 
This text taken from Contemporary Asian Art and Exhibitions: Connectivities and world-making, by Michelle Antoinette and Caroline Turner, published 2014 by ANU Press, The Australian National University, Canberra, Australia. 